\title{
DESCRIPTIONS OF ROBBER FLIES OF THE GENUS ERAX.
}

James S. Hine.

The predatory habits of robber flies are of distinct value from the standpoint of one interested in economic entomology. A study of the genus Erax has resulted in bringing together nearly all the North American species. As a number of these are undescribed the following descriptions are published so that the names will be available in future work in the genus.

Erax plenus n. sp. A large, robust species, varying in length from 23 to 30 millimeters.

Male. Total length, 27 millimeters, antennæ black, style nearly twice as long as the third segment, palpi black and clothed with pale yellow hair, face and cheeks with abundance of pale yellowish hairs, ocellar bristles and several bristles on the upper part of the occiput black. Thorax yellow pollinose with most of the hairs and bristles black; wings with a very pale yellowish tinge, costa not thickened near the tip of the auxiliary vein, furcation of the third vein far before the base of the second posterior cell and with a distinct appendage, posterior branch of the third vein reaches the costa distinctly before the tip of the wing; legs clothed with pale yellowish hairs and black bristles, black, except the tibia which are largely reddish. First three abdominal segments dark, mostly with black hair above and white hair beneath, four white with long white hair parted in the middle and directed outward, five, six and seven white, hypopygium dark in color, short and somewhat tumid.

Female unusually robust for an Erax. Abdomen, except the ovipositor, uniformly pale yellowish pollinose, ovipositor shining black, about as long as abdominal segments five, six and seven combined. Otherwise colored as in the male.

Type male from Douglas County, Kansas, 900 feet elevation. (F. H. Snow).

Several specimens of each sex from the same locality, from Onaga, Kansas, and from Osborne County, Kansas, 1557 feet elevation, collected August 3, 1912. (F. X. Williams.)

A male from Onaga, Kansas, taken August 20, 1901, is like the other males except that abdominal segment seven is black instead of silver white. This gives the specimen quite a different appearance, but since similar variations have been observed in other species of the genus it is not considered specific here. 
Erax auripilus n. sp. A medium sized species characterized by abundance of rather bright yellow hair on all parts of the body.

Male. Total length, 22 millimeters. All the hairs on the various parts of the head yellow, sternum and sides of the thorax with yellow hair, dorsum with black hair, wings clear hyaline, furcation of the third vein distinctly before the base of the second posterior cell and with a long appendage, costa not enlarged near the tip of the auxiliary vein, posterior branch of the third vein meets the costa distinctly before the tip of the wing; legs with yellow hair and black bristles, in most part black in ground color but the basal half or more of each tibia is bright yellow; abdomen with yellow hair, segments two to five black above with light colored lateral and hind margins, segments six and seven silver white, hypopygium of medium size, shining black in ground color and clothed with yellow hair.

Type male taken at Clifton, Texas, May 29, 1907, by E. B. Williamson. A male in the collection of the Academy of Natural Sciences was taken at Round Mountain, Texas.

Erax canus n. sp.

Male. Total length, 24 millimeters. General body color rather hoary white produced by white pollen and hair, dorsum of the thorax with black hair and bristles, legs with black bristles, mystax and beard pale yellow, bristles of the front black, palpi black with pale yellow hair and bristles, wings hyaline, costa uniform throughout, furcation of the third vein distinctly before the base of the second posterior cell and with a distinct appendage, the posterior branch of the third vein bends forward to meet the costa plainly before the apex of the wing, legs black with the basal third of each tibia reddish; abdomen uniformly hoary white, segments two, three and four on the dorsum with long white hair parted at the middle and directed outward; hypopygium of medium size, black and clothed with white hair.

Female colored like the male, but abdominal segments two, three and four devoid of the peculiar long hair described for the male. Ovipositor shining black, slightly longer than abdominal segments six and seven combined.

Male type from Claremont, California, sent in by Carl F. Baker; females from the same locality. The smallest female measures only 17 millimeters in total length. 